\title{
PROFESSOR EDGAR ALEXANDER PASK
}

\author{
An Appreciation
}

Professor Edgar Alexander Pask, 51, died suddenly on May 30, 1966, at Newcastle upon Tyne. Thus departed one of the great figures in the world of anaesthesiology. Since I had the privilege of knowing him intimately for many years, and since he had a great interest in Canada, I would like to write a few words of personal tribute to him.

I first met "Gar" Pask shortly after the war, when he was still a SquadronLeader in the Royal Air Force and had just been decorated with the O.B.E. for outstanding and courageous service in medical research. His exploits on active service were many, and mostly unsung, but one of his achievements did bring him recognition-that was in helping to solve the problem of self-righting life jackets for unconscious airmen "ditched" in the sea. Stuffed dummies were tried in efforts to simulate victims in such a situation, but results were unsatisfactory. So Pask offered himself as the "guinea pig," and many times he was given deep ether anaesthesia, intubated with a cuffed endotracheal tube attached by yards of rubber hose to an Oxford vaporizer (this was long before the days of our present efficient respirators) and thrown into a wave-stirred pool. Various designs of life jacket were tried on this human dummy, and eventually one was adopted which saved many lives. Thus Pask earned the O.B.E., but he acquired also the poor health which plagued him for the rest of his life.

At that time Wesley Bourne and I were dreaming about the possibility of setting up a research professorship in McGill's new Department of Anaesthesia. When we met Pask we were so impressed by his wisdom, his wit, his modesty, and his transparent honesty that we determined he was the man we wanted for McGill. The next thing we heard was that Pask had been appointed Professor of Anaesthetics at Durham University in Newcastle upon Tyne, the first full chair of anaesthesia in Great Britain, other than the Nuffeld chair at Oxford, where, working under Macintosh, Pask had received most of his anaesthesia training. There followed several years of frustrating negotiations. Pask came to Montreal to work with us for several months in 1950, and again in 1951. The more we saw of him the better we liked him, but we had no money or special facilities to offer, and he had family responsibilities in England which he felt at that time prevented him from migrating to Canada. Finally, early in 1955, a new possibility opened up. The Wellcome Trust of London, under the chairmanship of Sir Henry Dale, agreed to contribute $\$ 125,000$ to McGill to establish a chair of anaesthesia research, and to maintain it for five years. This offer was made mainly on the assumption that Professor Pask would accept the appointment. Pask agreed, and everything seemed to be happily settled. But the next news we had was that he was not well. He had had his health carefully assessed by eminent English consultants, and the reports were so inauspicious that he felt it would not be fair 
to McGill or to his own family to pull up his roots in view of such an uncertain future. So we went back in fear and trembling to the Wellcome Trust to see whether the money would still be forthcoming for some other man. Pask and I visited Sir Henry Dale in London, and found him to be sympathetic and understanding. He agreed to accept whomever Pask thought qualified for the position. So that is how Gordon Robson came to McGill as the first Wellcome Research Professor of Anaesthesia.

My own friendship with "Gar" Pask seemed to grow even warmer as the years went on. He came often to visit us in Montreal. I was frequently in England and always spent some time with him, either in Newcastle or London or at one of the beauty spots which he knew and loved so well. It was he who introduced Linda and me to the pleasures of driving through the quiet by-ways of Britain. He showed us the beautiful hills of North Wales, the Lake District, the moors of the border country, Blanchlands Abbey, and the rhododendrons of "Cragside." One day he drove us into Kent, through Rochester and Canterbury and Folkstone and Hythe, so that I could re-live the summer I spent there in 1915 before going off to war in France.

Pask had an encyclopaedic mind-he seemed to me to be an authority on almost everything, a lucid and entertaining speaker, and yet the most modest of men. Never was there a more devoted son, or a more conscientious physician. All of those who worked with him adored him, and their only complaint-as was minewas that he never spared himself. The details of his career, his education, his appointments, his leadership in professional organizations, his contributions to anaesthesia literature and research, his work for the Royal Life Saving Society, and his countless other activities will all be suitably recorded elsewhere. These few words are just in simple and affectionate tribute from Linda and me to our dear friend "Gar" Pask. Our hearts go out in sympathy to his wife, Muriel, and his little daughter, Susan.

Harold R. GRTFTrth, M.d.

Emeritus Professor of Anaesthesia, McGill University 